\title{
Input Structures, Output Functions, and Systems Capacity: A Study of the Mineworkers' Union of Zambia
}

\section{Citation}

Bates, Robert H. 1970. Input structures, output functions, and systems capacity: A study of the Mineworkers' Union of Zambia. Journal of Politics 32, no. 4: 898-928.

\section{Published Version}

http://dx.doi.org/10.2307/2128388

\section{Permanent link}

http://nrs.harvard.edu/urn-3:HUL.InstRepos:3374527

\section{Terms of Use}

This article was downloaded from Harvard University's DASH repository, and is made available under the terms and conditions applicable to Other Posted Material, as set forth at http:// nrs.harvard.edu/urn-3:HUL.InstRepos:dash.current.terms-of-use\#LAA

\section{Share Your Story}

The Harvard community has made this article openly available.

Please share how this access benefits you. Submit a story.

Accessibility 


\section{CAMBRIDGE \\ UNIVERSITY PRESS}

\section{Southern Political Science Association}

Input Structures, Output Functions, and Systems Capacity: A Study of the Mineworkers' Union of Zambia

Author(s): Robert H. Bates

Source: The Journal of Politics, Vol. 32, No. 4 (Nov., 1970), pp. 898-928

Published by: Cambridge University Press on behalf of the Southern Political Science

Association

Stable URL: http://www.jstor.org/stable/2128388

Accessed: 24/08/2009 14:44

Your use of the JSTOR archive indicates your acceptance of JSTOR's Terms and Conditions of Use, available at http://www.jstor.org/page/info/about/policies/terms.jsp. JSTOR's Terms and Conditions of Use provides, in part, that unless you have obtained prior permission, you may not download an entire issue of a journal or multiple copies of articles, and you may use content in the JSTOR archive only for your personal, non-commercial use.

Please contact the publisher regarding any further use of this work. Publisher contact information may be obtained at http://www.jstor.org/action/showPublisher?publisherCode=cup.

Each copy of any part of a JSTOR transmission must contain the same copyright notice that appears on the screen or printed page of such transmission.

JSTOR is a not-for-profit organization founded in 1995 to build trusted digital archives for scholarship. We work with the scholarly community to preserve their work and the materials they rely upon, and to build a common research platform that promotes the discovery and use of these resources. For more information about JSTOR, please contact support@jstor.org. 


\title{
INPUT STRUCTURES, OUTPUT FUNCTIONS, AND SYSTEMS CAPACITY: A STUDY OF THE MINEWORKERS' UNION OF ZAMBIA*
}

\author{
ROBERT H. BATES \\ California Institute of Technology
}

INTRODUCTION

I

$\mathrm{n}$ this article, we study the attempts of the Government of Zambia to render the Mineworkers' Union of Zambia an agency for implementing development policies.

The Union was founded in 1948. Although its emergence resulted in large part from indigenous industrial grievances, it also grew out of the efforts of the colonial government to forestall the attempts of European miners to organize their African counterparts. Not only did the government fear the power of a comprehensive mineworkers' union, it also recognized that a major objective of the European miners was to prevent the economic and racial advancement of the African workers that would result from an independent African union. The new African union made rapid progress. By 1956, it had increased earnings by more than $200 \%$ for its highly paid members and by more than $400 \%$ for its members at the bottom of the pay scale. ${ }^{1}$ The Union also became increasingly militant. When in 1956 it initiated a series of "rolling" strikes-over the companies' recognition of an African staff association-the colonial administration arrested and detained nearly all its leaders. Following these detentions, the Mineworkers' Union slowly regained its position of strength in the copperbelt. Its power was best revealed in the successful attempts of its leaders to repel the efforts of the nationalist movement to gain control over the Union. In the post-

${ }^{*}$ I wish to acknowledge the support given to this project by the Institute for Social Research of the University of Zambia, the Foreign Area Fellowship Program, the National Science Foundation, and the Center for International Studies of the Massachusetts Institute of Technology. Some of the materials are drawn from my forthcoming book, Unions, Parties, and Political Development: A Study of Mineworkers in Zambia, and are published with the permission of Yale University Press. None of these institutions, of course, is in any way responsible for the content of this article.

${ }^{1 P}$. K. Lomas, "African Trade Unionism on the Copperbelt," South African Journal of Economics, 26 (June 1958), 120. 
independence period, the Union was faced by a new challenge: that of adjusting to governmental policics aimed at rapid economic development. $^{2}$ The manner in which the Union met this challenge forms the topic of this article.

The study casts light on one of the dominant trends in contemporary African politics: the transformation of voluntary associations and other "para-political" organizations-trade unions, youth leagues, cooperative societies, and so forth-into agencies of governmental rule. ${ }^{3}$ To some degree, the transformation is motivated by the desire of ruling elites to regulate the emergence of potential counter elites and to neutralize potential centers of opposition. ${ }^{4}$ There are other motivations, however, among which the most prominent is the desire to "ensure ... that the activities of such groups are congruent with and supportive of the modernization objectives of the regime."

The assertion of governmental control over associational structures is of interest to more than just Africanists, for the trend bears directly upon crucial points in general development theory. Insofar as the transformation of para-political structures by African elites is an attempt better to realize development goals, it represents an ef-

${ }^{2}$ The best general history of the Union is contained in A. L. Epstein, Politics in an Urban African Community (Manchester: Manchester University Press on behalf of the Rhodes-Livingstone Institute, Northern Rhodesia, 1958). See also the relevant sections of David C. Mulford, Zambia, The Politics of Independence 1957-1964 (London: Oxford University Press, 1968); and Robert I. Rotberg, The Rise of Nationalism in British Central Africa: The Making of Malawi and Zambia 1873-1964 (Cambridge: Harvard University Press, 1965). For an analysis of party-Union relations see Elliot Berg and Jeffrey Butler, "Trade Unions," in Political Parties and National Integration in Tropical Africa, ed. by James S. Coleman and Carl G. Rosberg, Jr. (Berkeley and Los Angeles: University of California Press, 1964). The tensions between the European and African union focused on the issue of African advancement; perhaps the best discussion of this topic is contained in Nan S. Waldstein, "The Struggle for African Advancement in the Copper Industry of Northern Rhodesia" (Center for International Studies, Massachusetts Institute of Technology, Cambridge, Mass., 1957).

"See, for example, the "Introduction," in Political Parties and National Integration in Tropical Africa, ed. by James S. Coleman and Carl G. Rosberg, Jr.; and Martin L. Kilson, "Authoritarian and Single Party Tendencies in African Politics," World Politics, 15 (January 1963), 262-294.

"This is essentially the position argued by Martin L. Kilson, "Tensions and Dynamics of Single-Party Systems: Case of the Erstwhile Convention People's Party" (paper presented at the annual meeting of the American Political Science Association, Washington, D.C., 1968).

"James S. Coleman and Carl G. Rosberg, Jr., "Introduction," 7. 
fort to enhance the capacity of their political systems. And insofar as it involves the recasting of interest groups into agencies for implementing public policies, it entails the transformation of input structures into structures performing output functions. ${ }^{6}$ This trend gives rise to several theoretical questions for which we seek answers in this study: How successful is this strategy for increasing system capacity? To what degree can input structures perform output functions? Is there a contradiction between the capacity to perform input and the capacity to perform output functions?

Our study contributes to a third area: the growing body of literature on labor and development. In attempting to render the Mineworkers' Union an instrument of government policy, the Government of Zambia is recapitulating the histories of a host of other countries. As the work of Kerr and his associates, Galenson, Myers, Friedland and others have shown, trade unions have been asked by governments to switch from "consumptionist" to "productionist" roles for the sake of rapid development." Our study will suggest

${ }^{6}$ For a discussion of these concepts in general development theory see the "Introduction," in The Politics of the Developing Areas, ed. by Gabriel A. Almond and James S. Coleman (Princeton: Princeton University Press, 1960); and Gabriel A. Almond and G. Bingham Powell, Jr., Comparative Politics, A Developmental Approach (Boston: Little, Brown and Company, 1966), 25-30.

'The best general books in this field are Clark Kerr, John T. Dunlop, Frederick H. Harbison, and Charles A. Myers, Industrialism and Industrial Man (New York: Oxford University Press, 1964); and Walter Galeson, ed., Labor and Economic Development (New York: John Wiley and Sons, 1959). There have been studies of analogous trends in communist countries. See, for example, the sections on East Germany in Reinhard Bendix, Work and Authority in Industry (New York: Harper Torch Books, 1956); and Isaac Deutscher, "Russia," in Comparative Labor Movements, ed. by Walter Galenson (New York: Russell and Russell, 1958). There is a burgeoning literature on this topic in Africa. See, for example, G. E. Lynd, The Politics of African Trade Unions (New York: Frederick A. Praeger, 1968); Jean Meynaud and Anisse Salah-Bey, Trade Unionism in Africa, Its Growth and Orientation (London: Methuen and Co., Ltd., 1967); William H. Friedland, "Basic Social Trends," in African Socialism, ed. by William H. Friedland and Carl G. Rosberg, Jr. (Stanford: Stanford University Press, for the Hoover Institution, 1964); Michael F. Lofchie and Carl G. Rosberg, Jr., "The Political Status of African Trade Unions," in The Role of Labor in African Nation-Building, ed. by Willard A. Beling (New York: Frederick A. Praeger, 1968); William H. Friedland, "Labor's Role in Emerging African Socialist States," in The Role of Labor in African Nation-Building, ed. by Willard A. Beling; Roger Scott, The Development of Trade Unions in Uganda (Nairobi: East African Publishing House, 1966); Joan Davies, African Trade Unions (Harmondsworth: Penguin Books Ltd., 1966). The best single bibliography is William H. Friedland, Unions, Labor, and Indus- 
the limits of the productionist role of unions and the constraints imposed upon elites who seek to reorder the role of labor.

\section{BACKGROUND}

Like many developing countries, Zambia possesses a "singlecrop" economy; it is based overwhelmingly on the production of copper. According to official figures, in 1960, the copper industry alone contributed $50 \%$ of the gross domestic product; in 1966, the figure was $41 \%$. For decades, copper has made up more than $90 \%$ of the value of Zambia's exports. ${ }^{8}$ As the "free-world's" second largest copper producer, Zambia is clearly a "single-crop" country; and copper, in the local term, is the "backbone of [our] economy," or more colorfully, "[our] copper cow."

Zambia shares another characteristic with her "third-world" partners: its government is committed to a program of rapid and pervasive economic development. The magnitude of the government's commitment is perhaps best reflected in the rate of economic growth it seeks to attain: an annual increase of $11 \%$ in the gross domestic product, in real terms, over the seven-year period of 1964 to $1970 .{ }^{10}$

Because of the strong position of the copper industry, a full $62 \%$ of the $£ 524.8 \mathrm{~m}$ that the government has earmarked for development purposes for 1966-70 is to come from tax revenues on copper production. While the mines' proportion of the government's tax bills is to decline to $57.6 \%$ over the four-year period, it is to rise as high as $69.0 \%$ for a single given year. Thus, the copper mines are expected to be the single greatest financial contributor to Zambia's development effort. ${ }^{11}$

The government has elaborated a series of policies designed to protect and nurture the financial position of the mining industry

trial Relations in Africa, Cornell Research Papers in International StudiesIV (Ithaca: Center for International Studies, Cornell University, 1965).

${ }^{8}$ Copper Industry Service Bureau, Copperbelt of Zambia Mining Industry Year Book 1967 (Kitwe: CISB, 1968), Table 2, 33.

${ }^{9}$ President Kaunda, "Speech to the Governing Council of the Zambia Congress of Trade Unions," Press Release, Zambia Information Department, November 29, 1965, 15.

${ }^{10}$ Republic of Zambia, First National Development Plan 1966-1970 (Lusaka: Office of National Development and Planning, July 1966), 5-6. ${ }^{11}$ Ibid., 14. 
and to increase the country's ability to benefit from the prosperity of the copper industry. Thus, in 1966, the government imposed an export tax designed to take advantage of the inflated world price of copper; in 1968, the government placed a limit of $50 \%$ on the profits the industry could remit abroad; and in 1969, the government purchased a $51 \%$ share of the copper industry. ${ }^{13}$ A last set of policies are intended to shape and structure the behavior of the labor force so that the mining industry can prosper for the benefit of the nation. The government's labor policy may be characterized as a "development labor policy."

\section{Government Labor Policy}

One illustration of the government's dedication to a development labor policy on the mines is the preoccupation of government spokesmen with discipline in the mines' labor force. Discipline refers to three primary areas: hard work, respect for supervisors, and the strict observance of established procedures for resolving industrial disputes.

The government advocates "hard work" while condemning "loafing," "laziness," and "self-centeredness." The development orientation of government labor policy emphasizes that the role of the mineworkers is to contribute to rapid economic growth: when the workers fail to work hard, they are refusing to assume their proper role in the nation and become "saboteurs." 14 The worker's self-indulgence represents a betrayal; to redeem themselves and to assume an honorable place in the system, employees must vindicate themselves by working hard.

The government, again in the name of discipline, strongly reaffirms the authority of the supervisor. The African workingman's triumph in the seizure of political power, the government declares, is not to feed back into the structure of industrial authority. Because the creation of taxable wealth requires the exercise of mana-

${ }^{12}$ See the account by Richard L. Sklar, "Zambia's Response to U.D.I.," Mawazo (June 1968), 11-32.

${ }^{13}$ The rate of the export tax is $40 \%$ of the amount, if any, by which the average London Metal Exchange (LME) price per long ton of copper exceeds $£ 300$. When the price of copper is less than $£ 300$ on the LME, then the tax falls away.

${ }^{1+}$ Minister of Labour, "Speech to Labour Relations Course, Kitwe," Press Release, Zambia Information Department, February 25, 1967, 10. 
gerial authority, "the responsible position of the supervisor must be recognized by all levels and he should be enabled to exercise his function without fear or favor from any source."15

Discipline also refers to the scrupulous observance of procedures for resolving industrial disputes in the mines. In particular, it refers to the exercise of restraint in redressing grievances-a willingness to bargain and negotiate instead of walking off the job. The government's resolve to end strikes is indicated by the public pledge it elicited from workers' representatives: "when any dispute arises of any nature ... the employees must follow the provisions of any disputes' procedure existing between them [and their employers] rather than resorting to unconstitutional ... action." 16

If discipline is the slogan for those aspects of labor policy just described, productivity is the slogan most frequently employed in public utterances on wages policy. The government fears the effects on economic growth of rapid wage increases. It fears inflation, the loss of foreign exchange, and the inhibition of investments that would result from such increases. ${ }^{17}$ Equally as powerful as all these considerations, however, is the elite's conviction that wage rises in excess of increases in productivity would expand the workers' share of corporate revenues-an expansion that would take place at the expense of the government's share. Since such increases threaten the taxable margin of corporate revenues, they are regarded by the government as encroachments by the workers upon the resources available for public purposes. ${ }^{18}$ Given the recent nationalization of the mines, the competition between the government and workers for corporate profits is even more direct. As a result of these considerations, the government has added a further principle to its policy toward mine labor: "For the next few years . . . any substantial improvement in wages and other conditions

15Ministry of Labour, "A Code for Industrial Peace in Zambia," Code adopted at the Livingstone Labour Conference, Livingstone, Zambia, April 1967, paragraph 6 .

16Ministry of Labour, "Pledge to the National Development Plan," Pledge adopted at the Livingstone Labour Conference, Livingstone, Zambia, April 1967, 1.

${ }^{17}$ Republic of Zambia, "Evidence of the Brown Commission of Inquiry, 1966," Testimony taken in Lusaka, Zambia, June 21, 1966, 74-75.

${ }^{18}$ See, for example, the analysis given in Assistant Labour Commissioner, "Speech to the Congress of Trade Unions," Press Release, Zambia Information Department, December 9, 1967, 5. 
must be balanced by corresponding improvements in productivity." 19

These, then, are the essential tenets of the government's development labor policy. The government utilizes two principal strategies for implementing its policy. The first is to advance the racial status of the mine employees-to champion their cause as Africans -in exchange for their cooperation as industrial workers. ${ }^{20}$ This policy has born fruit in an immensely successful program of localization: the personnel departments of all the major copper companies, as well as the supervisory grades of the underground and major surface departments, are now largely filled by local employees. ${ }^{21}$ As a goal in and of itself-a goal for which many fought during the anti-colonial struggle-the policy of localization has been highly successful. $^{22}$ As a tactic, however, localization has failed; for, as we shall see, the government's efforts to attain advancement for the workers have not evoked the cooperation of the workers with the government's development program.

What is of prime importance here is the government's second strategy: its attempts to render the workers' own representative, the Mineworkers' Union of Zambia, an agency for implementing government policy. ${ }^{23}$ From the perspective of development theory,

${ }^{19}$ Minister of Labour, "Speech to Labour Relations Course, Kitwe," 5.

"In part, this exchange is tacit. Evidence for it is the government's sense of outrage and betrayal when the workers counter its development policies; this outrage is expressed in terms of "how can they do this to us, after we have brought them the benefits of independence," i.e., Zambianization, the elimination of racial disparities in facilities on the mines, and so forth. The exchange is also explicit. Thus, the Minister of Labour, after reviewing the Zambianization program, declared: "In the words of a king who reigned in Palestine about 3,000 years ago-'my father (or read "my stepfather, the late, unlamented colonial regime of unhappy memory") chastised you with whips but I will chastise you with scorpions. My stepfather made your burdens heavy, but I will make them ten times heavier.' Because the greater the privilege, the greater the responsibility." Minister of Labour, "Speech to Conference of Trade Unionists," Press Release, Zambia Information Services, July 29, 1968, 7.

${ }^{21}$ Republic of Zambia, Ministry of Zambia, The Progress of Zambianization in the Mining Industry (Lusaka: Government Printer, December 1968).

${ }^{22}$ Perhaps the best single discussion of the history of this struggle is Waldstein, "African Advancement in the Copper Industry." For a report on the success of the program, see Republic of Zambia, Progress of Zambianization in the Mining Industry.

${ }^{23}$ See the contents of the speeches listed above. Perhaps the most explicit description of the post-independence role of organized labor is con- 
the unionists are asked to alter their conception of their role and of the function of unions. Rather than performing solely as officials of an input structure, the unionists are asked to perform output functions for the larger political system. From the perspective of the study of labor and development, they are asked to switch from a "consumptionist" to a "productionist" role. Instead of an exclusive commitment to advancing the interests of their members in higher wages, in their grievances against supervisors, and in their desire to work less hard while receiving greater pay, the union leaders are instead asked to perform their duties as conscientious spokesmen of the public interest. As one government official states: "It is the patriotic duty of the Union to pursue constructive and responsible policies because it is these policies which will serve the people in their struggle for economic progress." ${ }^{24}$

\section{The Failure of Government Policy}

Our data suggest that the government's policy toward mine labor has largely failed. The determinants of industrial discipline and productivity are many and various, and the nature and conduct of unions is but one factor out of many. We cannot accurately assign a weight to this factor. But we do affirm that an examination of the role of the Union is significant, if only because the ability of unions to perform development functions is regarded as an important question by governments and scholars alike. Our data suggest that while the national officials of the Union-the Head Office-support government policy, they are unable to use the Union to evoke the support of the miners for the government's program.

\section{Response of the Head Office}

My interviews with the seven national-level officials of the Mineworkers' Union-the Head Office of the Union-convinced me that they accept the government's conception of the role of the Union. They think in national terms, viewing the mining industry in relation to other sectors of the economy and especially in relation to the government's economic objectives. The leaders frequently

tained in the speech by the Assistant Labour Commissioner, "Speech to the Congress of Trade Unions."

${ }^{24}$ President Kaunda, "Speech to the Governing Council," 7. 
refer to Zambia as a "new" nation and regard the government's development goals as necessary for Zambia. They fully realize that they represent the labor force of the wealthiest sector of the economy; from this realization, they derive a sense of responsibility for the economic well-being of Zambia as a whole. This pattern of thinking can be detected in the following statement by the current President of the Union:

The Union cannot have the idea that its duty is to do something for the members alone. The duty of the Union is to a wider field, to develop the country as Zambia is. No, we cannot have the same ideas as we had before independence; as a new nation, we must adopt a program that will benefit the country as a whole and not just our members. ${ }^{25}$

The Head Office's commitment to the broad outlines of government policy translates into commitments to particular points of the policy as well. Thus, while the national leaders do not consider it appropriate to exhort their members to work hard, they have served notice of their unwillingness to protest management action against workers with poor work records. ${ }^{26}$ The Head Office has given elaborate assurances to government and management of its intentions to uphold the authority of supervisors. ${ }^{2 \pi}$ And it has strived to curtail strikes. ${ }^{28}$

While endorsing the need for discipline proclaimed in the government's labor policy, the Head Office is more equivocal in its support of the exhortation to productivity. National officials are profoundly aware of the disparity between the wages of local and ex-

25Interview, May 27, 1967.

${ }^{26}$ This position was most explicitly elaborated by the General Secretary in a talk delivered to the Ministry of Labour's Labour Relations Course, June 14, 1967.

27Thus, the Head Office of the Union gave elaborate assurances when the Union incorporated the supervisory grades into its field of jurisdiction in 1967. Inserted into the agreement between the companies and Union was a new clause (paragraphs 1.1.3[b]) which stated: "The Union agrees that it will not take disciplinary action against any employee ... on account of the performance of his duties, and in particular of any supervisory duties as an employee of the company." Copper Industry Service Bureau, "Local Conditions of Employment and Service, 1968," Issued by the Copper Industry Service Bureau, Kitwe, Zambia, February 1968.

${ }^{23}$ Whenever there are strikes, members of the Head Office go out to persuade the miners to return to work. This is now a fixed pattern in industrial relations in the mining industry. 
patriate workers on the copper mines, and they believe that higher wages for their members are justified. ${ }^{29}$ Nonetheless, in their actual conduct, they support the government's position. In 1965, the Head Office declared a dispute with the companies over a major wage demand. Following Rhodesia's unilateral declaration of independence in 1965, however, the Head Office drastically reduced its wage claim, negotiated an agreement, and campaigned intensively among the mineworkers for their acceptance of the agreement. ${ }^{30}$ In so reacting to the Rhodesian crisis, the Head Office was clearly motivated by consideration for the well-being of the nation.

\section{Response at the Local Level}

The government has succeeded in developing an output orientation among the national leaders of the Union. But if the government assumes that the support and collaboration of the national leaders of the Union will translate into support from the mass of the members, it appears to have erred. It is extremely difficult to marshal concrete data on this point. Nonetheless, the available data reinforce the conclusion that the Union leaders have failed to evoke support from the workers for the government's labor program.

Hard Work: There are two indicators of the miners' response to the governmental injunction, "work hard." One is the frequency of various kinds of offenses, such as absenteeism. The other is various measures of productivity. The scope of the two sets of data is highly restricted, for the data on offenses pertain only to two departments at one mine and the data on productivity refer to underground operations at but two mines. Nonetheless, the indicators

${ }^{29}$ For example, expatriate employees doing the same work as Africans receive $165 \%$ to $254 \%$ more in pay, according to figures presented to me by the Ministry of Labour. To be noted, however, is that the Unions and company have just negotiated a single, basic wage scale, whereby Africans and expatriates doing the same work receive the same basic wage; expatriates, however, are entitled to an expatriate bonus.

${ }^{30}$ As noted in the Republic of Zambia, Report of the Commission of Inquiry into the Mining Industry, 1966 (Lusaka: Government Printer, 1966), there was reason to believe that the Union wanted a quick agreement, in any form, in order to forestall an attack by a rival union, the United Mineworkers' Union (UMU). As Head Office officials cogently argue, however, the best way for them to have fought off UMU would have been to press militantly for a major wage increase; their action would have made them popular with the mass of the workers. 
all point in one direction, and they conform to both management's and government's impression of the behavior of the mineworkers. ${ }^{31}$ Insofar as the indicators in Tables 1-3 measure the effort of the miners, there has been a decrease in the mineworkers' commitment to hard work since the year of independence (1964).$^{32}$

Obedience: Penalty records also yield an insight into the miners' response to the second principle of government policy: that supervisors should be obeyed. Tables 4-6 indicate that there has been an enormous increase in the failure or refusal of workers to obey the instructions of supervisors since independence.

My own data, gleaned from the monthly reports of labor officers in the mine towns, also indicate a precipitous rise in insubordination in the post-independence period. Using the frequency of protests

TABLE 1

Offenses, Rhokana Mine

\begin{tabular}{lrrrrrr}
\hline & & & & & \multicolumn{2}{c}{$\begin{array}{c}\text { Percent } \\
\text { Increase or Decrease }\end{array}$} \\
Offenses Reported & 1964 & 1965 & 1966 & 1967 & Uncorrected Corrected \\
\hline Absenteeism & & & & & & \\
$\quad \begin{array}{l}\text { Central Shaft } \\
\text { Smelter }\end{array}$ & 445 & 678 & 980 & 1007 & +126 & +113 \\
$\begin{array}{l}\text { Work Strength on } \\
\text { the Mine }\end{array}$ & 9414 & 289 & 418 & 401 & +76 & +63 \\
\end{tabular}

${ }^{\text {a}}$ Rhokana Corporation, "Comments on Questions arising from Productivity Seminar, 12 February, 1968."

'Adjusted for changes in the mine's labor strength.

${ }^{31}$ Evidence of the government's concern is the spate of "Productivity Seminars" that the President convened on the copperbelt in the early months of 1968. Included were many cabinet officials and officials from the United National Independence Party (the government party in Zambia), the Mineworkers' Union, and the mining companies.

${ }^{32}$ Another major factor influencing productivity would be technological change. Insofar as there have been such changes, they have all been designed to increase, not decrease, productivity, and so would not account for the reductions reported above. A second additional factor would be the disruptions produced by Rhodesia's break with Great Britain. However, to the extent that this affected the mines, by limiting fuel supplies, etc., the effects were largely upon smelting operations, and not upon underground production. During the early months of UDI, the mines stockpiled unsmelted and unrefined ores; underground operations continued. As these figures measure productivity underground, they are largely uninfluenced by the effects of UDI. 
TABLE 2

Productivity, Rhokana Minea

\begin{tabular}{lrrrrr}
\hline & & & & & Percent Decrease \\
\cline { 6 - 7 } Measure & 1964 & 1965 & 1966 & 1967 & $1964-1967$ \\
\hline $\begin{array}{l}\text { Tons per Man Shift } \\
\text { (Mining) }\end{array}$ & 3.980 & 3.661 & 2.833 & 3.187 & 19.92 \\
$\begin{array}{l}\text { Feet Drilled per } \\
\text { Machine Shift (Roto) }\end{array}$ & 96 & 89 & 94 & 80 & 16.67 \\
$\begin{array}{l}\text { Feet Drilled per } \\
\quad \text { Machine Shift (Perc) }\end{array}$ & 108 & 105 & 92 & 92 & 14.81 \\
$\begin{array}{l}\text { Feet Advanced per } \\
\quad \text { Machine Shift }\end{array}$ & 7.83 & 5.42 & 4.87 & 5.22 & 33.33 \\
$\begin{array}{l}\text { Tons Lashed per Shift } \\
\text { (Central and S.O.B.) }\end{array}$ & 5.15 & 4.63 & 4.39 & 4.48 & 13.01 \\
\hline
\end{tabular}

${ }^{a}$ Rhokana Corporation, "Comments on Questions arising from Productivity Seminar, 12, February, 1968."

TABLE 3

Productivity, Roan Antelope Minea

\begin{tabular}{lcccccc}
\hline Measure & 1963 & 1964 & 1965 & 1966 & 1967 & $1963-1967$ \\
\hline $\begin{array}{l}\text { Tons per Man Shift } \\
\text { (Mining) }\end{array}$ & 4.58 & 4.42 & 4.32 & 3.76 & 3.40 & 25.76 \\
$\begin{array}{l}\text { Feet Drilled per } \\
\quad \text { Machine Shift }\end{array}$ & & & & & & 47.00 \\
$\begin{array}{l}\text { Tons Broken per } \\
\text { Stoping Shift }\end{array}$ & & & & & & 34.00 \\
\hline
\end{tabular}

${ }^{a}$ Copper Industry Service Bureau, "Transcript, Productivity Seminar Luanshya and Ndola, 6 January, 1968."

against supervisors as an index of insubordination, my data strongly suggest that workers accord a much lower level of respect to their supervisors than that advocated by the government. ${ }^{33}$

Strikes: In this area, too, the mineworkers have failed to respond to the government's advocacy of peaceful resolution of industrial conflicts. My own data (Table 7) indicate that not only has the abso-

${ }^{33} \mathrm{My}$ data also reveal that the Head Office, in conformity with its general support of government policy, does not participate in this trend. Despite the fact that $53 \%$ of all protests against supervisors since 1950 have taken place since 1963, only $30 \%$ of the total number of Head Office protests against supervisors have taken place since that time. 
TABLE 4

Number of Offenses Reported by Year, Rhokana Mine ${ }^{a}$

\begin{tabular}{lrrrrrrr}
\hline & & & & & \multicolumn{2}{c}{$\begin{array}{c}\text { Percent } \\
\text { Increase or Decrease }\end{array}$} \\
\cline { 5 - 7 } Offenses Reported & 1964 & 1965 & 1966 & 1967 & Uncorrected Corrected \\
\hline Failing to Obey & & & & & & \\
$\begin{array}{l}\text { Instructions } \\
\quad \text { Central Shaft }\end{array}$ & 60 & 74 & 121 & 383 & +538 & +525 \\
$\quad \begin{array}{l}\text { Smelter } \\
\text { Refusing to Obey }\end{array}$ & 11 & 26 & 41 & 97 & +782 & +769 \\
$\begin{array}{l}\text { Instructions } \\
\quad \text { Central Shaft }\end{array}$ & 22 & 20 & 26 & 60 & +172 & +159 \\
$\quad \begin{array}{l}\text { Smelter } \\
\text { Work Strength on } \\
\text { the Mine }\end{array}$ & 29 & 52 & 44 & 142 & +390 & +377 \\
\hline
\end{tabular}

${ }^{\text {a}}$ Rhokana Corporation, “Comments on Questions arising from Productivity Seminar, 12 February, 1968.”

TABLE 5

Number of Offenses Reported by Year, Roan Antelope Minea

\begin{tabular}{lrrrc}
\hline & & & \multicolumn{2}{c}{$\begin{array}{c}\text { Percent } \\
\text { Increase or Decrease }\end{array}$} \\
\cline { 3 - 5 } Offenses & 1964 & 1965 & & Uncorrected Corrected \\
\hline Failing to Obey Instructions & 374 & 590 & +58 & +53 \\
Work Strength on the Mine & 7412 & 7766 & +5 & \\
\hline
\end{tabular}

${ }^{a}$ Copper Industry Service Bureau, “Transcript, Productivity Seminar Luanshya and Ndola, 6 January, 1968." 9.

TABLE 6

Protests Against Supervisors

\begin{tabular}{lccc}
\hline & $1950-1963$ & $1964-1968$ & Total \\
\hline $\begin{array}{l}\text { Number of Protests } \\
\quad \text { Against Supervisors }\end{array}$ & 39 & 44 & 83 \\
$\begin{array}{l}\text { Percent of All Protests } \\
\quad \text { Against Supervisors }\end{array}$ & 47 & 53 & 100 \\
$\begin{array}{l}\text { Total Number Protests Made } \\
\quad \text { by Mineworkers }\end{array}$ & 396 & 177 & 573 \\
$\begin{array}{l}\text { Protests vs. Supervisors as } \\
\text { Percent Total Protests }\end{array}$ & 10 & 25 & 15 \\
\hline
\end{tabular}


TABLE 7

STRIKES

\begin{tabular}{lcc}
\hline & $1950-1963$ & $1964-1968$ \\
\hline Strikes & 75 & 86 \\
Percent of Total Grievances & 18 & 49 \\
Non-Strikes & 321 & 91 \\
Percent of Total Grievances & 81 & 51 \\
Total Number of Grievances & 396 & 177 \\
\hline
\end{tabular}

lute number of strikes increased since self-government was attained but also the number of grievances that result in strike action. Since the country gained its independence, however, not a single strike has received official support from the Union; all have been "wildcat" strikes. My findings are corroborated by government data, which indicate a $300 \%$ increase in the number of strikes on the mines between 1960 and $1966 .{ }^{34}$

Productivity: Government policy on productivity has suffered a similar fate: basic mine wages increased 30\% between 1964 and 1966. Wages can increase, however, for reasons other than increases in basic wages; demands for increased bonuses, shift differentials, and job regradings, also lead to increased wages. Since the attainment of self-government, this sort of "hidden" wage demand has increased in frequency: whereas $76 \%$ of all wage demands were hidden demands prior to self-government, the number rose to $86 \%$ thereafter. $^{35}$

\section{Explanation}

To explain the failure of the Union to function as an output agency, we must first specify more closely our notion of the output process. In our usage, the term refers to the flow of policy from the governing elite to the leadership of the major para-political groups and from the leadership of those groups to the rank and file.

${ }^{34}$ Ministry of Labour, Department of Labour Annual Report(s), 1960-1966 (Lusaka: Government Printer, 1961-1967).

${ }^{35}$ Once again, the Head Office refuses to be a party to this trend. Before 1963, it took part in 54\% of all these "hidden" wage increases; since then, it has advanced only $19 \%$ of these demands. 
The term further implies that the policies, once disseminated, are enforced. There are thus three main dimensions to the conception of the output process: the responsiveness of the organization's leadership, the transmission of policies through the organization, and the enforcement of policies by the leadership. We will briefly indicate the reasons for the failure of the Mineworkers' Union to perform each of these tasks successfully.

\section{Responsiveness}

One of the primary reasons for the failure of the Union to serve as an output structure is that, while the Head Office is willing to commit the Union to the implementation of government policy, the local branch leaders are not. Perhaps the basic reason for the divergent responses of the two levels is the uneven distribution of incentives to cooperate with the government. While the government has made it in the private interest of the Head Office to support public policy, it has failed to provide corresponding incentives for the local leadership.

Many of the government's inducements are psychological. It seeks to promote and develop a sense of national status and prestige among the Head Office leaders by recruiting them to governmental committees (such as the Zambianization Committee); through public confirmations of status (by sharing public platforms with Union leaders at national rallies, patriotic celebrations, etc.); and through the regularized process of consultations at the ministerial level. As a result of the government's campaign for their support, the Head Office unionists come to see themselves as public figures and not merely as the spokesmen for a small sub-group of the nation. The local branch leaders do not receive these inducements, however; the government fails to involve them in the tasks and ceremonies that generate a sense of public significance among their superior officers. Instead, the local branch officials remain active solely at the local level; they continue to see themselves as members of the labor force, with interests identical to those of the mass of the miners. And they remain committed to the championship of the interests of labor, rather than to the public interest as articulated by the government.

The mix of incentives contains material rewards as well. For members of the Head Office of the Union, mobility into the public 
TABLE 8

Government Experience of Head Office Members:

OFFICEHOLDERS IN THE 1960s

Number Currently Employed by Government

Number Who Had Government Posts in the Past

Number With No Government Experience

Total Officeholders Since 1960

TABLE 9

Current Status of Head Office Members in the 1960s

Fired by Company

Deceased

Staff Jobs in the Union

Officeholders at Branch Level

Company Employment in Jobs

Outside the Union's Jurisdiction 1

Government Service

1

1

Still in Office

2

2

2

Total Officeholders Since 1960

sector is a realistic career prospect. Tables 8 and 9 reveal that there are plentiful opportunities for government service for members of the Head Office.

The incentive of government employment is used to evoke commitment to public policy. As one high public official declared:

It would be wise for Union leaders to know that there are many vacancies in the Government services which have not yet been filled. . . But jobs will not be given to people who are the cause of trouble and friction. The Government does not want Union leaders as M.P.'s or Parliamentary Secretaries who cause trouble . . .36

The government fails to extend the inducement of upward mobility to the local level. ${ }^{3 i}$ To the best of my knowledge, only one branch leader has received promotion to government office; branch

${ }^{36}$ Source confidential.

${ }^{37}$ There is evidence of a change of government policy on this matter. Thus, the Ministry of Labour and the Congress of Trade Unions are increasing their efforts to recruit local branch leaders into government training courses. Their program will culminate in the courses to be offered at Mulungushi Citizenship Training College, when the facilities are completed. 
officials must first achieve Head Office posts before they can bring themselves to the attention of the political elite. ${ }^{38}$

The Structure of Power: The Head Office is unable to evoke cooperation from the members largely because it lacks the power to enforce its point of view upon the local leadership. The structure of power in the Union allocates control over Union activities to the militant branch leaders. As a result, the Head Office is unable to maintain at the local level leaders who actively support and disseminate government policy. The pattern of power is revealed in the composition of the Union bodies that govern the performance of goal attainment and internal maintenance activities.

The goal of the Union is to gain concessions from management. As one would expect, at the local plant level, the negotiating committees are composed entirely of local branch officials. More surprising is the local branches' control over negotiations at the industrial level as well. Suggestions for items for bargaining with the Chamber of Mines are solicited from the local branch committees. Items are chosen for the negotiating agenda by the Annual Conference; in 1967, of the 55 members of the Annual Conference, 48 came from the local branch level. The local branch leaders also dominate the committee that actually conducts industry-wide negotiations; in 1967, seven of the eleven members of the national negotiating committee were local branch officials. The divergent fortunes of the items submitted by the local and national leaders of the Union, shown in Table 10, reveal that the process of goal attainment favors the local branch officials.

TABLE 10

Items for National Negotiations, 1963, By Origin

\begin{tabular}{lccc}
\hline & $\begin{array}{c}\text { Total } \\
\text { Number }\end{array}$ & $\begin{array}{c}\text { Number from } \\
\text { Branches }\end{array}$ & $\begin{array}{c}\text { Number from } \\
\text { Head Office }\end{array}$ \\
\hline $\begin{array}{l}\text { Items Submitted for Industry-Wide } \\
\quad \text { Negotiations }\end{array}$ & 67 & 57 & 10 \\
$\begin{array}{c}\text { Items Selected for Negotiating Agenda } \\
\text { by the Annual Conference }\end{array}$ & 17 & 14 & 3 \\
$\begin{array}{c}\text { Items Won or Compromised in Nego- } \\
\text { tiations at the Industrial Level }\end{array}$ & 7 & 5 & 2 \\
\hline
\end{tabular}

${ }^{38}$ The sole exception is the late Hanky Blackskin Kalanga, an M.P. and junior minister, who was formerly Chairman of the Union's branch at Rhokana. 
A similar situation exists with the body that controls the process of internal maintenance: the Supreme Council of the Union. The Supreme Council makes appointments to staff positions, rules on promotions and salaries, controls finances, and exercises internal discipline (fining, suspending, or dismissing union officials). In 1967, local branch officials held 21 of the 24 posts on the Supreme Council.

Another in cation of the structure of power in the Union is the manner in which the Head Office leaders are recruited. ${ }^{39}$ They are elected at the Annual Conference of the Union, which is essentially an electoral college composed of the local branch leaders.

The structure of power in the Union thus favors the local branch officials. Conversely, it places the Head Office leaders at a severe disadvantage in their efforts to gain acceptance of government policy at the local level. One illustration of this dilemma arose in 1963, when the Head Office strove to reduce the frequency of strikes in the mines; as the following minutes reveal, they were helpless in the face of local opposition:

The meeting [of the Supreme Council] was opened by the President [of the Union] who said that the reason it was called was on account of the strikes at present taking place on the Copperbelt, and that ways and means must be found to end these continual stoppages. . . .

The Chibuluma Branch Secretary reported that his branch would go on strike at 2 a.m. on Saturday 5/1/63, the reason for the strike being that a member of the Union was beaten up by a foreman and a policeman. . . . The Head Office officials pointed out that if the Branch ... had notified the Head Office of their intention to call a strike, Head Office officials could have intervened and the strike could have been avoided.

A member of the Roan delegation ... reported that the Roan Antelope [Branch] would go on strike again. ${ }^{40}$

Equally as dramatic is the transformed role of the Head Office since 1963, the year of self-government. Given its endorsement of

${ }^{39}$ The Head Office leaders are all "old timers" who have worked their way up through the local branch level or through the paid staff of the Union's bureaucracy. On the average, they first became Union officers 11.3 years ago. In no sense, therefore, have they been imposed on the Union by the government. The governing party, the United National Independence Party, however, has tried to influence and control the recruitment of Head Office leaders; but despite the vigor of these efforts, they have not been effective.

40 "Report on the Supreme Council meeting of January 8, 1963," File 100.20.7J. 
government policy, one would expect it more frequently to ameliorate and reduce local disputes and less often to exacerbate them than in the period before self-government was achieved. Instead, as Table 11 indicates, the Head Office more frequently does nothing. This pattern seems to reflect the dilemma in which the Head Office is cast by the structure of power in the Union.

TABLE 11

Role of the Head Office, Pre- and Post-Self-Government in Zambia

\begin{tabular}{lcc}
\hline Percent of Cases in Which & & \\
the Head Office: & $1950-1963$ & $1964-1968$ \\
\hline Dampens the Activities of the Local Branch & 5 & 2 \\
Remains Passive & 21 & 9 \\
Takes Over the Dispute & 6 & 0 \\
Exacerbates the Activities of the Local Branch & 64 & 78 \\
Fails to Get Involved &
\end{tabular}

${ }^{\mathrm{a}} \mathrm{F}$ or example, it visits the branch and local management to gather information about the dispute.

The Structure of Communications: Given the failure of the government to elicit support for its policies at the local level of the Union and the inability of the Head Office to impose its views upon the local branch leaders, Union officials at the local level do not transmit the content of government policies to the rank and file. Even if they were to do so, however, the Union would most probably fail as an output agency. For its communication structure, while wellsuited to the detection and upward transmission of demands, is ill suited to the downward transmission of the officials' points of view, especially when they are at variance with the opinions of local members. Since the labor policy of the government requires predictably unpopular sacrifices by labor, the communication structure of the Union thus reduces its value as an agency for transmitting this policy.

The Union has two primary channels of communication: its network of local officials and public meetings.

The Union's network of officials appears perfectly adequate for the detection of the members' grievances. At Rhokana mine-the mine I studied-there were over 60 shop stewards distributed throughout the plant area; by agreement with the company, 
workers were free to approach the stewards at any time. In addition, the Union maintained an office outside the mine gates. After every shift, the workers stopped in to report their grievances to branch officials, and all the shop stewards were required to check in to report on the state of their departments. In this manner, the Union leaders rendered themselves a "captive" audience to the members and thereby kept in close touch with the sentiments of the rank and file.

While well-suited for upward communications, the network of officials is ill-suited to the downward transmission of messages. With a branch membership in excess of 10,000 , the network of Rhokana officials is too small to enable the union leaders to reach the members on a regular, face-to-face basis or to achieve total coverage of the membership as an audience for its opinions, let alone instructions. ${ }^{41}$ In addition, the very fact that the Union officials and membership come into contact when the members are aggrieved ensures a strong element of selective exposure in the structure of face-toface communications. ${ }^{42}$

To increase its capacity for downward communications, the Union takes recourse to mass membership meetings. Public meetings, however, fail significantly to augment the capacity for downward communications. The other major indigenous organization on the copperbelt is the United National Independence Party (UNIP); using its performance as a standard of comparison, we can see from Table 12 that Union meetings are fairly infrequent and poorly attended. ${ }^{43}$ When the attendance figures are broken down by individual mines, they yield average attendance figures of $16 \%$ of the employees at Mufulira, $4 \%$ at Roan, $10 \%$ at Nchanga, and

${ }^{41}$ For a discussion of the role of selective exposure in forestalling opinion change, see Joseph T. Klapper, The Effects of Mass Communications (New York: The Free Press, 1960). For a discussion of the role of face-to-face, union networks in overcoming selective exposure and resistance to opinion change by industrial workers, see the analysis of East German unions in Bendix, Work and Authority in Industry.

${ }^{42} \mathrm{By}$ contrast, UNIP maintains a network of nearly 200 officials at Rhokana. The party officials see their role as one of initiating downward communications and not merely of processing grievances. Through small, cell structures (party sections, organized on a territorial basis in the townships), party officials can sustain intensive face-to-face agitation in support of public policies.

${ }^{43}$ As the table in the text reveals, UNIP meetings are very well attended. UNIP leaders employ their network of party officials to marshal attendance at meetings. 
$5 \%$ at Rhokana. During the 14 months I was in Nkana, UNIP held 12 public meetings while the Union held 2 . The average attendance at party meetings was in the thousands; at Union meetings it was around 100 persons.

TABLE 12

Public Union Meetings, June-November $1962^{\mathrm{a}}$

\begin{tabular}{lcccccccc}
\hline & \multicolumn{3}{c}{ Mineworkers' Union } & & \multicolumn{3}{c}{ United Nat. Indep. Party } \\
\cline { 2 - 3 } \cline { 6 - 8 } & $\begin{array}{c}\text { Number of } \\
\text { Meetings }\end{array}$ & $\begin{array}{c}\text { Average } \\
\text { Attendance }\end{array}$ & $\begin{array}{c}\text { No. of } \\
\text { Towns }\end{array}$ & $\begin{array}{c}\text { Number of } \\
\text { Meetings }\end{array}$ & $\begin{array}{c}\text { Average } \\
\text { Attendance }\end{array}$ & $\begin{array}{c}\text { No. of } \\
\text { Towns }\end{array}$ \\
\hline June & 9 & 964 & 7 & & 7 & 1,446 & 1 \\
July & 0 & 0 & 0 & & 7 & 3,650 & 4 \\
August & 2 & 425 & 2 & & 8 & 1,829 & 5 \\
September & 2 & 45 & 2 & & 6 & 4,967 & 4 \\
October & 2 & 290 & 2 & & 9 & 1,930 & 3 \\
November & 1 & 24 & 1 & & 4 & 1,300 & 3 \\
\hline
\end{tabular}

aNchanga, Nkana, Roan, and Mufulira Mines. There is no information for November 15-30. During this period, both of the organizations were at a peak of activity. UNIP was in the midst of its campaign for the 1962 elections, and the Union was in the midst of its dispute over African advancement. The dispute led both to a national strike and to a Commission of Inquiry: the Morrison Commission. From File 100.20.7.

Public meetings are an effective means of communication when the leaders wish to express views with which the members agree. Thus, when the officials call meetings for the purpose of militant action, attendance increases. Evidence for this pattern is contained in the attendance statistics for the Chibuluma Mine for 1961-62. The average audience at branch meetings for the two-year period was 350; but from April to August 1962, when the Union was preparing for strike action, the average attendance climbed to over $800 .^{44}$ The meetings are ineffective, however, when the officials seek to communicate unpopular messages. For example, when Union officials counsel restraint in wage demands or the postponement of strike action, the miners become enraged, the meetings often break up, and the audience disbands. At one meeting I observed, when the Branch Chairman reminded the audience that "our government is against unconstitutional action and wildcat strikes," he was shouted down and nearly assaulted.

${ }^{44}$ Attendance figures from File 100.20.7F. Chibuluma was selected because it has complete data for this time period. 
Thus, the communication structure of the Union favors upward communications. The network of Union officials can detect the members' grievances and the public meetings facilitate communications when the leaders and members are in agreement that the members' demands must be served. But neither channel can reduce the pattern of selective exposure and neither can ensure the downward transmission of unpopular points of view. This pattern bodes ill for the use of the Union as a means of transmitting a policy of restraint and sacrifice in conformity with development objectives.

\section{Enforcement}

The remaining dimension of an output structure is the capacity of that structure to evoke compliance with collective policies. In evaluating the Union along this dimension, we concentrate upon its relation with the mining community in which it operates and resides. The Union lacks legitimacy in the local mining community and hence lacks capacity to enforce compliance with moderate policies.

Role Performance: The local officials conceive of their role as one responsible for gaining substantive concessions from management. They define their role in terms of a purposive exchange: the enforcement of the basic rules of the industry in exchange for respectful attention from management to their demands. It is their belief that the exchange is in the long-term interests of the Union. By enforcing management rules, they argue, the Union gains management's respect; by gaining respect, it can win more cases and thereby increase its popularity among the rank and file.

The leaders' conception of their role frequently makes them appear as agents of management. They filter cases that are appealed through them. They reserve their energetic fights for cases in which there clearly is no violation of the plant rules; in other cases, they plead for management's mercy in the light of the worker's long service or large family and chastize the worker for putting them in so awkward a position. In addition, Union officials actively disseminate plant rules. By publicizing the rules, they feel that they can reduce the frequency of "bad cases." In other instances, they have no choice but to enforce the rules before they can obtain favorable settlements; when there are wildcat strikes, for example, they must 
get the workers to return before management will negotiate. To win management's respect, moreover, Union officials often strive to be ideal workers: punctual and conscientious, completing all the work before leaving their shift. By performing in this manner, they believe their supervisors will pay attention when they appeal members' cases.

Because of the way in which the Union officials perform their roles, they are frequently considered managerial spokesmen. Insofar as they gain management's respect, they lose the respect of their members. Many workers do not see the Union as the spokesman of their interests; they see it as an agency of management. When the Union leaders counsel restraint, their counsel is frequently rejected as reflecting the will of the company and not the advice of leaders with the members' interests at heart.

Social Status: Further undermining the capacity of the leaders to gain compliance with their views is their status in the mining community. Not only do the leaders appear to work closely with management; they appear to profit unduly from this relation. For whatever reason, the Union leaders do earn better incomes than the average employee. While the average wage at Rhokana was K75.40 a month, the shop stewards earned an average of K82.68.45 Because of their higher wages, branch officials tend to live in the more prosperous section of the mine township. And in any given department, there is a high probability that the Union officials will possess better-grade jobs than those of the average employee. ${ }^{46}$

The greater advantages of the Union officials are not unexpected, and, in themselves, the advantages might not be damaging. But, when viewed in conjunction with the performance of their roles, the advantages are very damaging indeed. Rather than obtaining respect as the legitimate champions of the demands of their members, the leaders appear to the members to function as a privileged group, attempting to evoke cooperation from the workers in exchange for personal benefits. Once again, the result is the refusal

${ }^{45} \mathrm{~K}$ stands for Kwacha, the basic denomination of Zambian currency. $1 \mathrm{Kwacha}=10$ shillings sterling, pre-devaluation.

${ }^{46}$ Using an index of income to rank jobs, in the five departments that employ the vast majority of the work force at Rhokana (over 80\%), the Union's representatives tended to possess better jobs than the average employees. The departments are the three underground shafts, the smelter, and the refinery. 
of the members to accord respect to their requests for restraint in the conduct of labor relations. ${ }^{47}$

Perception of Effectiveness: The Union leaders believe that by achieving management's respect they will win more cases and thus gain the loyalty of the members. The effectiveness of the Union, they feel, will serve as a basis for its legitimacy.

Since we cannot measure the correlation between managerial respcct and union efficacy, we can test the theory only in part. Our data indicate that the Union is relatively effective; that it wins cases the members care about; and that the local branches, which are in closest contact with the members, are as effective as the national level of the Union.

Throughout its history, the Union has gained as great a percentage of favorable outcomes (36\%) as it has suffered setbacks (38\%). Since the attainment of self-government in Zambia, the Union's effectiveness has increased. While the Union gained victories or compromises in $34 \%$ of its cases before 1963, the proportion has increased to $43 \%$ since that time.

Using the propensity to strike over a given issue as an indicator of the intensity of feelings about that issue, it is apparent from Table 13 that the Union tends to gain favorable settlements on those issues that the members care deeply about.

There is also a positive coefficient of rank correlation between the tendency for issues to arise at the branch level and the ability of the Union to gain wins or compromises on these issues (Table 14).

Yet, despite its record of effectiveness, the legitimacy of the Union remains in doubt. At the Rhokana branch, the Union's effectiveness did not translate into feelings that the Union was in fact effective. The primary reason for this appeared to be that many

\footnotetext{
4iPerhaps I may be permitted to offer the following passage from my field notes as indicative of the consequences of this pattern: "At Muhango's work point, a shop steward announced the Union's coming meeting. His announcement was greeted with cries, 'To Hell with the Union. We give you five shillings a month and you haven't even promised us what you are going to do. .. . Part of the antagonism derived from the fact that it was known that the shop steward had just purchased a new van for collecting charcoal and that he had just received a new hat, i.e., he had just received a promotion. He had been a leading operator, but he is now a section boss." Field notes, March 15, 1968.
} 
TABLE 13

Union EFfectiveness and Issue Intensity

\begin{tabular}{lcc}
\hline Issue & $\begin{array}{c}\text { Rank on } \\
\text { Frequency } \\
\text { of Strikes }\end{array}$ & $\begin{array}{c}\text { Rank on Frequency } \\
\text { of Wins or } \\
\text { Compromises }\end{array}$ \\
\hline Bonus & 1 & 1 \\
Task & 2 & 6 \\
Labor Flow & 3 & 8 \\
Conduct of Supervisor & 4 & 2 \\
Hours & 5 & 9 \\
Union Jurisdiction & 6 & $11 \mathrm{r}_{\mathrm{s}}=+.16$ \\
Wages & 7 & 3 \\
Clothing & 8 & 10 \\
Union Rights & 9 & 7 \\
Township Matters & 10 & 5 \\
Dismissals & 11 & 4 \\
\hline
\end{tabular}

TABLE 14

UNion EFFECTIVENESS AND UNION LeVEL

\begin{tabular}{lcc}
\hline Issue & $\begin{array}{c}\text { Rank on } \\
\text { Frequency } \\
\text { of Strikes }\end{array}$ & $\begin{array}{c}\text { Rank on Frequency } \\
\text { of Wins or } \\
\text { Compromises }\end{array}$ \\
\hline Hours & 1 & 9 \\
Bonus & 2 & 1 \\
Conduct of Supervisor & 3 & 2 \\
Dismissals & 4 & 4 \\
Task & 5 & 6 \\
Clothing & 6 & 10 \\
Labor Flow & 7 & $8 \mathrm{r}_{\mathrm{s}}=+.34$ \\
Township Matters & 8 & 7 \\
Union Rights & 9 & 3 \\
Wages & 10 & 11 \\
Union Jurisdiction & 11 & \\
\hline
\end{tabular}

of the mineworkers interpret the branch leaders' quest for management's respect as prima facie evidence of their weakness. "Intungulushi shama union, tee sana-union leaders, they're hopeless." "They don't know how to fight." "They're cowards in front of the Europeans." I encountered these comments frequently. While the Union may succeed in exchanging cooperation with management for increased success in handling grievances, the Union fails to achieve a reputation as a powerful and effective champion of the interests of African labor. Because it fails to achieve this reputa- 
tion, the workers refuse to accord it the right to demand concessions and sacrifices, as required by government labor policy.

\section{The Consequences for System Capacity}

The Government of Zambia, we have argued, seeks to transform the Mineworkers' Union from an input structure, primarily concerned with the articulation of the views of its members, into an output structure, concerned with propounding and enforcing the labor policies of the governing elite. By so doing, we noted, the government seeks to enhance its capacity to promote purposive economic change. We have documented the failure of the government's labor policy and have attempted to relate the weakness of the Union as an output structure to this failure of government policy. It remains to assess the consequences for the capability of the Zambian political system.

The notion of capacity has two major referents: the ability of a political system to obtain its objectives and the ability of a political system to intervene and purposefully change its environment. In the case at hand, the two referents largely coincide, for a principal political goal of the Zambian government is rapid economic development. A fortunate consequence is that the performance of the Zambian political system is measurable; we can assess its capacity in terms of available economic indicators.

There can be no doubt that Zambia has achieved an impressive rate of economic growth; whether that high rate can be maintained is more doubtful. Over the four-year period 1963-66, the average annual rate of growth of the gross domestic product remained in the vicinity of $15 \%$ ( see Table 15 ).

TABLE 15

Gross Domestic Product by Year ${ }^{a}$

\begin{tabular}{ll}
\hline Year & $\begin{array}{l}\text { G.D.P. } \\
(£ \mathrm{~m})\end{array}$ \\
\hline 1963 & 202.2 \\
1964 & 234.8 \\
1965 & 274.1 \\
1966 & 322.6 \\
\hline
\end{tabular}

${ }^{a}$ Ministry of Finance, Economic Report(s) (Lusaka: Government Printer, 1964-67), constant prices. 
Equally as impressive is the rate of investment. In terms of capital formation, Table 16 reveals a strong and concerted effort to invest in productive capabilities. On a per-capita basis, allowing

TABLE 16

Gross, Fixed Capital Formation ${ }^{a}$ $(£ \mathrm{~m})$

\begin{tabular}{lrrrr}
\hline & 1963 & 1964 & 1965 & 1966 \\
\hline Private Enterprise & 20.5 & 27.2 & 37.8 & 45.6 \\
Public Sector & 12.4 & 10.9 & 22.4 & 41.0 \\
Total & 32.9 & 38.1 & 60.2 & 86.6 \\
\hline
\end{tabular}

${ }^{2}$ Ministry of Finance, Economic Report(s) (Lusaka: Government Printer, 1964-67).

for inflation as well as for population increases, the rate of growth of the gross domestic product over the four-year period exceeds $10 \%$ per annum.

The failure of the government's labor policy, however, threatens to undermine the government's capacity to maintain this rate of growth. Increased wages in the mining industry are resulting in higher costs and reduced balance of payments, both of which threaten to curtail Zambia's development effort.

Increased wages in the mining industry lead to increased wages in other sectors. Following a $22 \%$ increase in basic mine wages in 1966, wage increases followed in the civil services; commerce and industry; hotel and catering; building, contracting, and civil engineering; and agriculture and domestic service. Evidence from commissions of inquiry and interviews indicates that the increases in the mining industry were a prime motivation for the new wage demands. ${ }^{48}$

The results of the increases are threefold. Insofar as they increase the cost of living, they reduce the real rate of growth of the

${ }^{48}$ Thus, the report of the Commission on the causes of a teachers' strike in the Western Province: "Almost all the witnesses were in general agreement that the salaries paid to teachers . . . were too low. . . . The grievances seem to have been exacerbated by comparisons with the salaries paid to miners [and] to teachers in mine schools." Republic of Zambia, "Evidence, Brown Commission of Inquiry, 1966," Testimony Taken in Lusaka, Zambia, June 12, 1966, A 10-11. 
Zambian economy. ${ }^{49}$ In addition, they increase the costs of production-already one of the highest in Africa-thereby encouraging the postponement of planned investments. Faced with higher salaries and other forms of recurrent costs, the government already has had to reduce investment expenditures by $20 \%$ in the 1969 fiscal year. ${ }^{50}$ With increased costs, profit margins decline, reducing the government's tax base. Our calculations suggest, for example, that wage increases in the mines have resulted in a loss of $£ 3.3$ million in government revenues since independence.

The third major consequence of increased wages is the effect on Zambia's balance of payments. Since independence, copper exports have kept Zambia's trade balance in the surplus column. As Table 17 indicates, however, the surplus on current account is diminishing year by year, and a principal cause of the reduction is the rising purchase of foreign goods.

\section{TABLE 17}

Balance of Payments on Current Account ${ }^{a}$ (K 0,000$)$

\begin{tabular}{|c|c|c|c|c|c|c|}
\hline \multirow[b]{2}{*}{ Category } & \multicolumn{2}{|c|}{1964} & \multicolumn{2}{|c|}{1965} & \multicolumn{2}{|c|}{1966} \\
\hline & Export & Import & Export & Import & Export & Import \\
\hline Goods & 33,030 & 14,290 & 35,712 & 20,892 & 43,136 & 24,914 \\
\hline Services & 1,634 & 6,242 & 1,702 & 4,860 & 1,856 & 7,492 \\
\hline Investments & 1,376 & 8,290 & 1,702 & 6,254 & 1,756 & 7,554 \\
\hline Transfers & 2,156 & 1,816 & 2,382 & 2,728 & 1,250 & 2,204 \\
\hline Net Surplus & \multicolumn{2}{|c|}{$+7,558$} & \multicolumn{2}{|c|}{$+6,764$} & \multicolumn{2}{|c|}{$+5,834$} \\
\hline
\end{tabular}

${ }^{\mathrm{a}}$ Compiled from Republic of Zambia, Monthly Digest of Statistics (Lusaka: Central Statistical Office, 1965-68).

Breaking the goods category down into consumer and producer goods reveals that over $50 \%$ of the increase in goods imports are production items, but that the import of consumer goods is increasing at a far more rapid rate than that of producer items. The single most important determinant of the rate of foreign consumer pur-

${ }^{49}$ The cost-of-living index on all items for persons with lower incomes on the copperbelt ran from 101.8 in 1963 to 127.7 in 1967. Republic of Zambia, Monthly Digest of Statistics (Lusaka: Central Statistical Office, January 1968). It is widely held that the index underestimates actual cost increases; the Central Statistical Office is currently in the process of revising it.

${ }^{50}$ For 1969 , recurrent expenditures remained the same as in 1968 at 280 million dollars. Capital expenditures declined from the 1968 level of 236 million to 189 million dollars. 
chases is private income, and the increased inflow of consumer items is a natural result of the rate of increase in Zambia's wages. Our calculations reveal that, given a one-year time lag, increases in mine wages correlate with increases in consumer imports with $r=$ .93. The ability of Zambia to maintain a favorable trade balance and a capacity to import the producer goods necessary to preserve a rapid rate of economic growth is thus being undermined by the government's inability to contain increases in wages.

\section{ConClusion}

Our study gives rise to one last question: Is there an inherent incompatibility between the performance of input and output functions? At first glance, our data strongly suggest that there is. The Union leaders, in seeking to restrain the behavior of their followers, weakened their legitimacy as leaders, and hence their ability to shape the behavior of the members. This conclusion is based largely on observations at the local level, where the leaders' belief in the necessity of cooperating with the companies frustrated their ability to legitimate their leadership positions. Nonetheless, we must recognize that the same dynamics operate at the national level as well. Restrained by the demands of the government, the Head Office leaders cannot militantly champion the demands of the workers. And they are therefore unable to build up leadership positions that would enable them to implement unpopular public policies. The Head Office leaders, too, are trapped between the conflicting demands of those to whom they are accountable. ${ }^{51}$

Also supporting this conclusion is the finding that the structural requirements for the performance of output functions are more demanding than those for the performance of input functions. Thus, a decentralized power structure suffices for the performance of input functions. Lower-level leaders are in a better position to detect the grievances of the members than are the leaders at the center; and when the organization is designed to fulfill the demands of the members, it is appropriate that the lower-level leaders have the

${ }^{51} \mathrm{An}$ interesting analogy to this problem is that of the position of the African chief under colonial rule. See, for example, L. A. Fallers, Bantu Bureaucracy: A Study of Integration and Conflict in the Political Institutions of an East African People (Cambridge, England: Heffer and Sons, 1956); and Max Gluckman, Custom and Conflict in Africa (New York: The Free Press, 1955), ch. 2. 
power to act in response to these demands. However, when the organization is designed for the implementation of policy from the leaders at the center, then a hierarchical power structure is appropriate. Thus, while the decentralized power structure of the Union was perfectly in keeping with its role as an input structure, it frustrated the ability of the Head Office to commit the local leaders to the transmission and enforcement of a development labor policy.

Our contention is also sustained by the examination of the communications structure of the Union. The structure was well suited to the performance of input functions. The network of Union officials and the system of public meetings could detect and transmit the grievances of the members, and was effective in amplifying and sustaining large-scale, collective actions in support of the workers' demands. ${ }^{52}$ The structure was inadequate, however, in the performance of output functions. A comparison with other structures suggests the additional properties that the organization must possess to communicate downward effectively: a large and pervasive network of officials, and a cellular structure with inclusive, lowerlevel membership units through which officials can agitate in support of the government's conception of the public interest. ${ }^{53}$

Our evidence thus leads us towards the conclusion that there is an inherent incompatibility in the effective performance of input and output functions. Further reflection, however, leads us to see our materials in a radically different light. It was precisely the inability of the Union to perform input functions that weakened its ability to perform as an output structure. Rather than two functions being incompatible, the data suggest that no matter how difficult it may be in practice, the two must go together: the performance of input functions appears to be a prerequisite to performance as an effective output structure.

${ }^{52}$ The Union has conducted several effective national strikes. In 1952 , the Union conducted a three-week strike in support of a $2 / 3 \mathrm{~d}$ per shift increase in basic wages. Three years later, the Union sponsored an eight-week strike for a 10/8d increase. In August 1956, the Union initiated a series of jurisdictional disputes in protest against the companies' recognition of a staff association. In 1962, the Union again conducted a national strike over the issues of wages and advancement.

${ }^{53}$ See the comments on UNIP in note 42. Also, see Lucian Pye, Guerrilla Communism in Malaya (Princeton: Princeton University Press, 1956); and Philip Selznik, The Organizational Weapon (Glencoe, Illinois: The Free Press of Glencoe, 1959). 
Thus, we have seen that the inability of the local leaders of the Union to persuade the members to moderate their conduct was derived in large part from their failure to convince the members that they had their interests at heart and were willing and able to defend them effectively. Lacking legitimacy as the spokesmen of the workers' demands, they were unable to gain respect and obedience when they attempted to curb the demands. Unable to convince their members of their effective performance in an input capacity, the leaders lacked the capacity to perform in an output capacity and thus to enforce the government's development policy.

Our last conclusion has a direct bearing on the study of labor and development. It suggests that, paradoxically, the unions that continue to fulfill a consumptionist role may also best be able to perform a productionist role. A moderate degree of autonomy for the labor movement, and a willingness to allow it, within limits, to defend the interests of its members, may well be the necessary means for rendering trade-union structures powerful ancillary bodies for mobilizing support for development objectives. Ambitious elites who seek the cooperation of labor for their development programs will be well advised to sacrifice a portion of the future rate of economic growth as a means of increasing the power of the unions to assist in enlisting the cooperation of the workers.

The alternative to this strategy is, of course, the direct government regulation of the behavior of the workers; but the costs of this alternative are high, and whether they can be borne by the developing nations is questionable. Following direct intervention, the focus of the conflict between the goals of development and the interests of labor shifts from within the labor movement to the center of the public arena. As the conflict with the government becomes more visible, support for the governing elite erodes among the working classes. And as shown in Ghana, the Congo (B), and Dahomey, the labor movements may well possess the superior sanctions in instances of overt conflict in the developing areas. Necessity may thus dictate a policy towards organized labor that is less than optimal in an economic sense, but that enables existing labor movements to play a positive role in the attainment of public objectives. 